\title{
IMPROVING ENGLISH SKILLS FOR ELEMENTARY SCHOOL CHILDREN IN CITENGAH VILLAGE, SUMEDANG
}

\author{
Bernard HASIBUAN* and Farhat UMAR \\ Faculty Engineering Sahid University, Jakarta, Indonesia \\ *bernard_hasibuan@usahid.ac.id
}

\begin{abstract}
Citengah Village is one of the beautiful and exciting places in the Sumedang area that can be developed as a tourist destination. To achieve that goal, all preparations are required, including the English language skills of the children of Citengah elementary school. English learning at the elementary school level is one of the efforts to build qualified Indonesian people ready to compete globally. There are many obstacles found in English language learning in rural schools, such as student conditions, environment, and English teachers' competence. Therefore it is necessary to explain to students and teachers more accessible and fun methods of learning English. The implementation of English learning training consists of stages of introduction, learning, and evaluation. The introduction stage explained the importance of English language skills related to the development of tourism potential in Citengah and future challenges for millennials. At the learning stage, we begin to explain the existence of English as a language that should be seen as a culture and knowledge. At the evaluation stage, all students and teachers expressed delight with learning English that is not boring and helps to understand quickly. Complete Mastery of English includes four things: speaking, listening, reading, and writing. Given an explanation of how fun methods of learning English such as viewing pictures, playing, storytelling and singing.
\end{abstract}

Keywords: English language, teaching methods, elementary school children, Citengah, learning

\section{BACKGROUND}

Education is an essential asset for the progress of a nation; therefore, every citizen must and must follow the level of education, both elementary school education, elementary education, secondary and higher education. In terms of education, a child needs good service in the fulfillment of educational needs accompanied by an understanding of the child's characteristics according to his growth and development. Children have a fresh thinking ability that experiences a period called the golden age of the child to get stimulation from outside (Samad \& Tidore, 2015). This will be very helpful in adjusting the learning process for children with their age, needs, and conditions.

Education should be given to children early on so that they can recognize their environment quickly. Providing early childhood education is expected better to prepare children in the face of the future. Vocabulary mastery can start from what children can easily understand (Ghalebi et al., 2021). In providing education, children rely on parents and the environment, community, and formal schools such as Elementary School Children's Education and Kindergarten to Elementary School. In the current era of globalization, our country must give birth to a generation of scholars who can compete in the international world. To compete at the international level, we must be able to communicate internationally as well. The learning of foreign languages is expected to cultivate the seeds of the world's generation of boosters. English as a tool of expression requires high confidence for students (Roinah et al., 2017).

In major cities in Indonesia, there have been many traditional schools in terms of children's education, so the quality of education of children in big cities has been relatively better. However, another thing within rural areas is that they have not provided a good quality of education for their students. Moreover, access to difficult urban areas becomes one of the obstacles to advancing education in the countryside. Cisoka Village Citengah Village South Sumedang District Sumedang is one of the villages inhabited by only 27 Families. Located approximately 26 kilometers from the center of the Sumedang district government but has not received electricity supply from the State Electricity Company (PLN). It is located in the middle of the hills, surrounded by tea plantations owned by margawindu. The majority of the villagers work as tea leaf pickers owned by Margawindu company. There is no income or other activities run by the villagers other than tea gardening. Harvest tea leaves will become the economic income of citizens only once in 3 months.

However, this village can become a tourist destination, which does not close the possibility of becoming a choice of tourist destination for foreign tourists, so it is necessary to make efforts to improve the ability to communicate English for many parties. English in primary schools needs to continue to be taught, although problems arise in the implementation of English learning in elementary schools (Maili, 2018). Learning English is complicated for several reasons, including the low interest of students in English lessons, lack of support from parents and the surrounding environment, and the quality of English teachers who are considered low (Harlina \& Yusuf, 2020). Based on the input from the community of Citengah Village, it is considered very necessary to conduct coaching related to the interests of elementary school children in English. English in primary schools is needed because in the digital age, and all systems use English language introduction (Maili \& Hestiningsih, 2017).

\section{METHOD OF IMPLEMENTATION}

English learning is to develop English language skills contextually and accepted following the students' daily lives (Wijaya, 2015). The program of English 
learning activities that will be conducted in Citengah village will go through several stages:

1. Site survey and cooperation with partners in Citengah village

2. Conducting socialization about the existence of English learning activities in Citengah.

3. Conducting training activities to learn English.

The training activities go through several stages, namely:

a. Introduction At this stage of introduction, children are introduced using daily communication in English. The introduction was not devoted to the names of objects only in English but also introduced a standard way of communicating in English.

b. Learning At the time of learning hours, children are taught by learning methods to play not to be saturated during the learning, given several tools supporting the learning system, and introduced how to use the supporting tools.

c. Evaluation is held after the children understand the learning. Assessment of each child is based on activeness during learning. After the Evaluation, it is expected that the children do not forget what they have gained during the learning. Moreover, at the same time, it is expected that they have the provision to continue their education to the next stage.

\section{RESULTS AND DISCUSSION \\ Preparation of Teaching Materials}

For the success of English teaching for children is required a combination of methods and suitable teaching materials. Teachers should be creative in finding teaching methods tailored to trainees (Apriani et al., 2021). Some of the methods used are image simulation, question, answer, discussion or chatting with fellow trainee children, singing, and some small games. In English teaching, it is necessary to note interactions in the classroom to improve participants' acceptance (Syafryadin et al., 2021). The teaching materials used are some images tailored to the topic being discussed. Some teaching materials are as follows (see Figure 1):

\section{English Language Learning Training}

The implementation of English language learning training consists of stages of introduction, learning, and evaluation. At the introduction stage, we explained the importance of English language skills related to the development of tourism potential in Citengah and future challenges for millennials who have to compete in the global market. English mastery can use an app that makes it very easy for learning (Wang \& Han, 2021). We also outlined a little problem why most Indonesians lack confidence because English is the third language after the mother tongue of their respective regions and the national language that is Indonesian.
At the learning stage, we begin to explain the existence of English as a language that should be seen as a culture and knowledge. As a culture, it must be built with customs such as the region's language they are good at. As a knowledge, we must learn grammar in English to complete the habits that have been developed. Complete Mastery of English includes four things: speaking, listening, reading, and writing. Given an explanation of how fun methods of learning English such as viewing pictures, playing, storytelling and singing. English teaching can increase children's enthusiasm for English mastery (Kasdi \& Wijayanti, 2017). Teaching English to children can use game methods that help participants understand quickly (Saraubon, 2021).

At the time of the training to learn English, two teachers wanted to learn fun teaching methods for the students. The teachers listen to how the coaching team started with an ice-breaking to dilute the atmosphere and prepare the students' audience to focus. Teachers are very aware of the need for constructive interaction in teaching to support achieving learning objectives.

\section{Learning Evaluation}

Completed the training event, the implementing team evaluated by asking the participants about the training methods, the atmosphere in training, and the duration of the training time. All students expressed delight with the non-boring method of learning English and helped with quick comprehension. All students also like a relaxed but focused training atmosphere, making them less shy and afraid of not speaking English before. In terms of the training time duration, most students do not feel long because the training is in a relaxed atmosphere. They hope that this learning method and atmosphere will be in schools when they learn English subjects. The teachers also expressed pleasure in gaining practical knowledge on how to learn and teach non-rigid English. Accompanying teachers are inspired by a variety of alternative teaching methods tailored to the character of the student.

\section{Documentation of Teaching Implementation}

The following are some documentation of photos of the implementation of activities from the reception by the Head of Citengah Village, the opening by the Team Leader until the closing of the event.

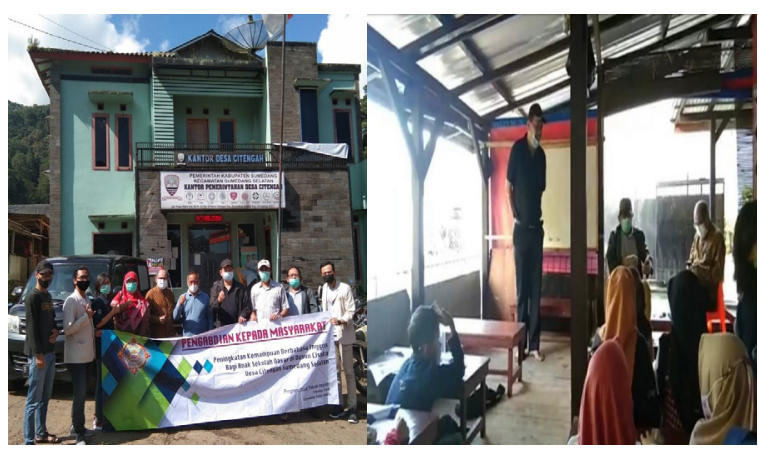

Figure 2. Team Acceptance by Citengah Village Head \& Opening by Team Leader 

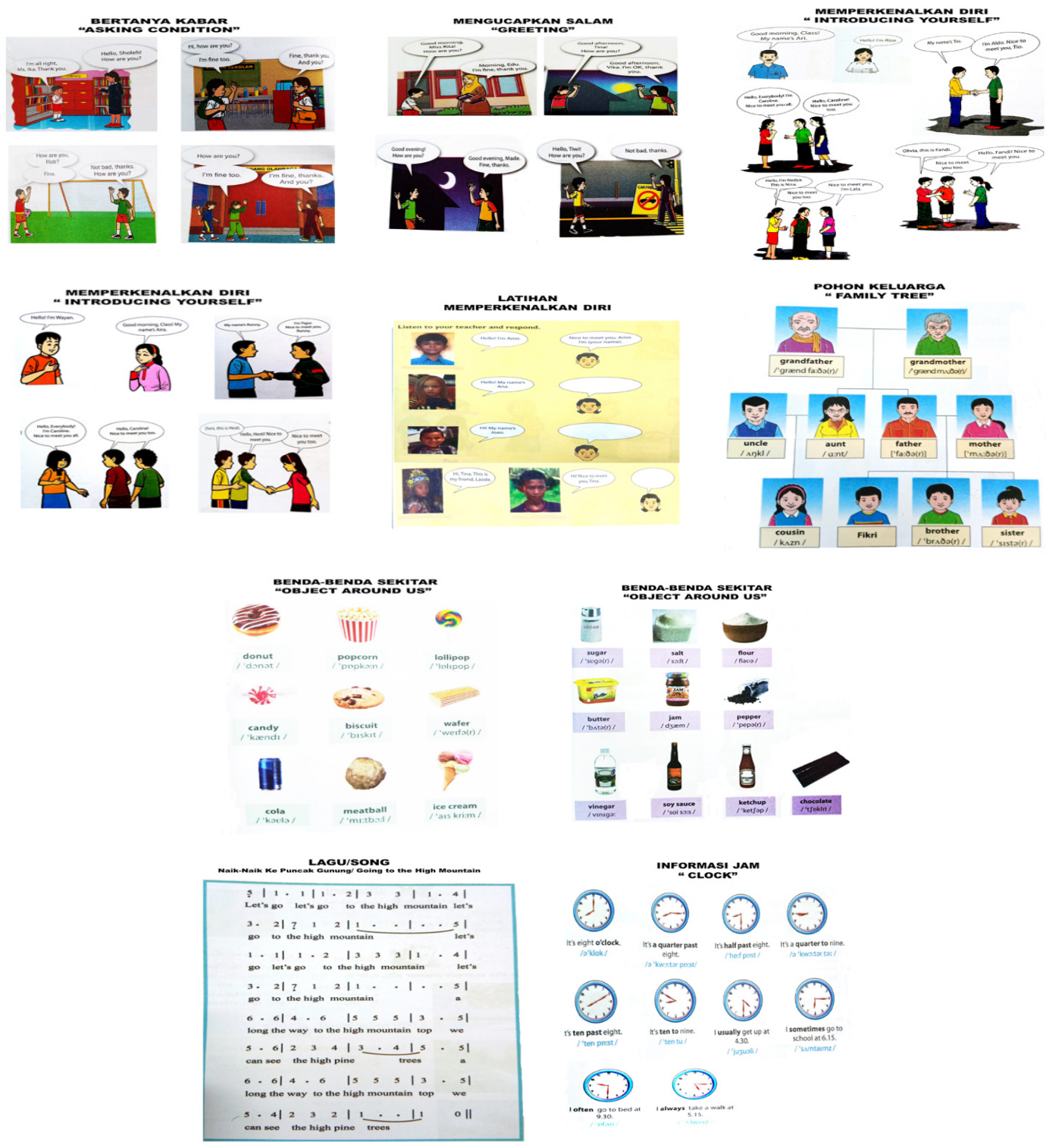

Figure 1. Learning process and training

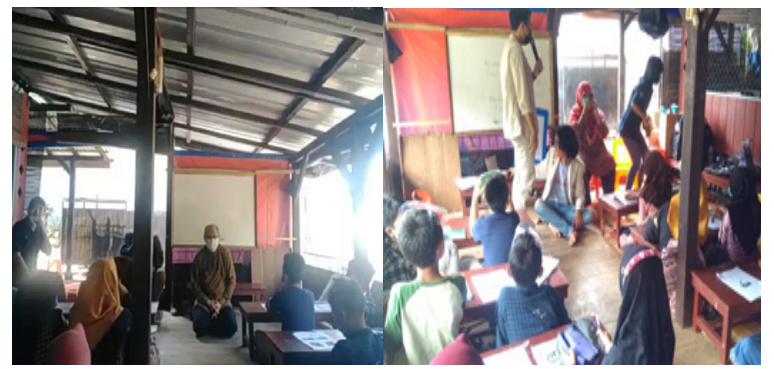

Figure 3. Explanation of activity plans \& Ice Breaking activities at the beginning of training

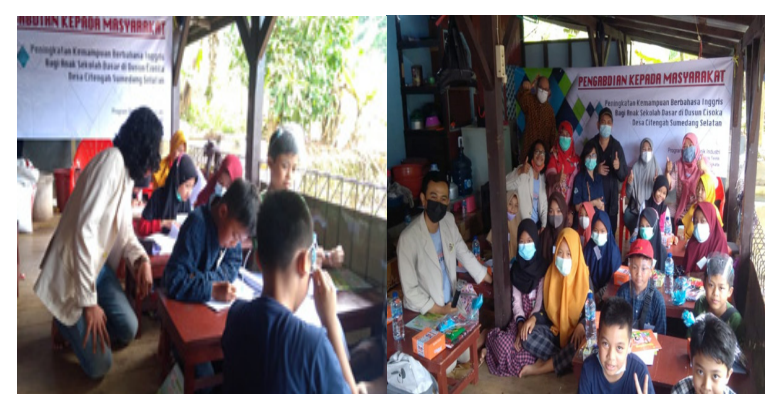

Figure 4. Mentoring by student assistants \& Take a cheerful picture together at the closing ceremony

\section{CONCLUSIONS}

This English language improvement activity provides a lot of input and inspiration for teachers and students in learning English. Teachers and students understand the importance of mastery of English to support the development of tourism potential in Citengah. From the training activities held, several conclusions can be drawn as follows:

1. The participation of children and teachers in participating in English training activities is quite active. Judging from the level of participation that remains in each training session until completion and present on time.

2. Most kids get additions about learning English that is easy and fun.

3. The students seem motivated and more eager to learn more English.

4. Students and teachers can discuss their obstacles in improving their interest and mastery of English with the coaching team. 
The suggestions for the development of this activity are:

1. There needs to be a follow-up from the Citengah Village government to continue this PKM activity, such as gathering students together while speaking English.

2. There needs to be a follow-up program from the Sahid University Team to make Citengah Village a target village considering many things that can be implemented in this village to implement higher education's tri dharma.

\section{ACKNOWLEDGMENTS}

We want to thank the Head of Citengah Sumedang Selatan Village, who has allowed the implementation of community service activities (PKM) to run, and to the teachers who accompanied when the training was carried out. On this occasion, we also express our deepest gratitude to the research and community service institute (LPPM) Sahid University Jakarta for the grants given to this PKM

\section{REFERENCES}

Apriani, E., Syafryadin, Inderawati, R., Arianti, A., Wati, S., Hakim, I. N., \& Noermanzah. (2021). Implementing E-learning Training toward English Virtual Lecturers: The Process, Perspectives, Challenges and Solutions. International Journal of Emerging Technologies in Learning, 16(4), 240255. https://doi.org/10.3991/ijet.v16i04.14125

Ghalebi, R., Sadighi, F., \& Bagheri, M. S. (2021). A study of vocabulary learning strategies among high and low Iranian English vocabulary learners. Cogent Education, 8(1). https://doi.org/10.1080/233118 6X.2020.1834933

Harlina, H., \& Yusuf, F. N. (2020). Tantangan Belajar Bahasa Inggris di Sekolah Pedesaan. Jurnal Penelitian Pendidikan, 20(3), 325-334. https://doi. org/10.17509/jpp.v20i3.28191

Kasdi, K., \& Wijayanti, D. N. (2017). Pembelajaran Bahasa Inggris Efektif Melalui Lagu Anak-Anak Untuk Siswa Madrasah Ibtidaiyah. ELEMENTARY:
Islamic Teacher Journal, 4(1). https://doi. org/10.21043/elementary.v4i1.1931

Maili, Sjafty Nursiti. (2018). Bahasa Inggris Pada Sekolah Dasar. Jurnal Pendidikan Unsika, 6(1), 23-28.

Maili, Sjafty Nursitti, \& Hestiningsih, W. (2017). Masalah-Masalah Pembelajaran Bahasa Inggris Pada Sekolah Dasar. Media Penelitian Pendidikan : Jurnal Penelitian Dalam Bidang Pendidikan Dan Pengajaran, 11(1), 54-62. https://doi.org/10.26877/ mpp.v11i1.2607

Samad, F., \& Tidore, N. (2015). Strategi Pembelajaran Bahasa Inggris Yang Menyenangkan Untuk Anak Usia Dini. Cahaya PAUD, 2, 47-57.

Saraubon, K. (2021). Development and evaluation of a mobile game as an English learning tool for ESL learners. International Journal of Advanced and Applied Sciences, 8(7), 77-83. https://doi. org/10.21833/ijaas.2021.07.009

Syafryadin, Harahap, A., Haryani, \& Astrid, A. (2021). Boosting classroom interaction based on higher order thinking skills (Hots) in english learning for beginners. International Journal of Language Education, 5(1), 477-489. https://doi.org/10.26858/ IJOLE.V5I1.15211

Wang, Z., \& Han, F. (2021). Developing English language learners' oral production with a digital game-based mobile application. PLoS ONE, 16 (1 January), 1-11. https://doi.org/10.1371/journal.pone.0232671

Wijaya, I. K. (2015). Pembelajaran Bahasa Inggris Di Sekolah Dasar. BAHTERA: Jurnal Pendidikan Bahasa Dan Sastra, 14(2), 120-128. https://doi. org/10.21009/bahtera.142.02

Roinah, R., Sigurdsson H., H. B. M. S. R. H. y S. J., Kasdi, K., Wijayanti, D. N., Suharso, Wijaya, I. K., Santosa, R. B., Zulkifli, N. A., Maili, S. N., Hestiningsih, W., \& Listia, Rina; Kamal, S. (2017). Pembelajaran bahasa inggris melalui. Jurnal Bahasa Dan Seni, 16(1), 120-128. 